\title{
New records to the flora of Uzbekistan (Middle Asia)
}

\author{
Komiljon S. Tojibaev, Natalia Yu. Beshko, Orzimat T. Turginov, \\ Farkhod I. Karimov, Avazbek Batashov, Mansur Usmanov \& Marcin Nobis
}

New records to the flora of Uzbekistan (Middle Asia). - Acta Mus. Siles. Sci. Natur., 66: 35-40, 2017.

\begin{abstract}
The Republic of Uzbekistan is a Central Asian country with rich native flora. The territory belongs to the Irano-Turanian region in the Ancient Mediterranean floristic subkingdom of Holarctic. The flora of Uzbekistan accounts over 4300 species of vascular plants including large numbers of endemic species, but the check-list is still incomplete. Presented here ten new records to the flora of Uzbekistan, were found during the field studies and examination of herbarium collections preserved at TASH.
\end{abstract}

Key words: phytogeography, new localities, Central Asia, vascular plants.

\section{Introduction}

The Republic of Uzbekistan is a Central Asian country with relatively large area of about $447,000 \mathrm{~km}^{2}$. The country occupies an important position in terms of biogeography. The territory belongs to the Turanian (or Aralo-Caspian) and Turkestan (or Central Asian mountain) provinces of the Irano-Turanian region in the Tethyan (Ancient Mediterranean) floristic subkingdom of Holarctic (Takhtajan 1986). The region is one of the world's centers of plant diversity. Almost $85 \%$ of the country is occupied by deserts; about $15 \%$ covered by mountains and foothills. The flora of Uzbekistan accounts more than 4300 species of vascular plants including large numbers of endemic, endangered and globally important species. During the last 20 years three new genera and about 100 new species were described or reported from Uzbekistan (Tojibaev 2009, Tojibaev \& Turginov 2013, 2014, Tojibaev et al. 2014a, 2014b, Nobis et al. 2016). However, the distribution of vascular plants requires further studies in many regions of Uzbekistan, such as the western part of the Zeravshan and Hissar Mts, Babatag Mts, Fergana Valley, etc. Both field studies and taxonomic revision of herbarium materials are currently performed. Since 2012, the research team of the Central Herbarium of Uzbekistan (TASH) compiling the digital database of plant diversity of Uzbekistan, with application of GIS software. The most important source of floristic information is TASH, the largest collection of Central Asian plants in the world. There are over 1.5 million herbarium specimens collected from all regions of the Central Asia since 1840. During 2012-2015, information from more than 75,000 herbarium specimens was included into the database and more than 110 new records in the flora of Uzbekistan were found. These results have a great importance for compiling the new checklist and flora of Uzbekistan (Sennikov et al. 2016). This paper provides information on ten new records to the flora of Uzbekistan. Occurrence of some of these species was previously given as present in western part of Pamir Alai Mts (e.g. in Conspectus flora Asiae Mediae 1968-1993) however with no specific localities, thus, the information weather this species is a component of the flora of Uzbekistan or not, was up to date unclear and required confirmation. 


\section{New records}

\section{Anthemis odontostephana Boiss. (Asteraceae)}

General Distribution: Central Asia (Kyrgyzstan) (Tscherneva 1962, 1993, Tscherneva \& Nikitin 1965, Lazkov \& Sultanova 2011).

OCCURRENCE IN UZBEKISTAN: Although Anthemis odontostephana has been listed as 'probably occur in Uzbekistan' its specific localities in this country has never been given. Specimen of that taxon preserved at TASH, was found in the end of the last century by F.O. Khassanov near Aktash settlement in Kugitang Mts.

SPECIMENS SEEN: Pamir Alai Mts, the southern end of the Kugitang ridge, $10 \mathrm{~km}$ to the south of the Aktash settl., 13 May 1984, leg. Khassanov (TASH)

\section{Chondrilla gibbirostris Popov (Asteraceae)}

General Distribution. Central Asia (Tajikistan) (Kinzikaeva 1991).

OCCURRENCE IN UZBEKISTAN: During revision of herbarium material preserved at TASH, we found two sheets with Chondrilla gibbirostris, collected in a western part of the Hissar Mts and not reported previously from Uzbekistan (Kovalevskaja 1959).

SPECIMENS SEEN. Baysun tau, the rocks in the gorge, Buzgala Khana between Derbent and Ak-Rabat, 1914, leg. M.G. Popov 661 (TASH); Hissar Mts, basin of Tupalang, Hurvatan, the slope of the Hurvatan river, 25 August 1947, leg. A. Pjataeva 375, (TASH, det. Togaev).

\section{Cousinia laniceps (Bornm.) Juz. (Asteraceae)}

Couisinia schtschurowskiana var. laniceps Bornm.

General Distribution: Central Asia (Kyrgyzstan), endemic to the Alai Mts (Tscherneva 1962, 1993, Tscherneva \& Nikitin 1965, Lazkov \& Sultanova 2011).

OCCURRENCE IN UZBEKISTAN: Base on the herbarium sheet, Cousinia laniceps was collected by Pyataeva, on the area of Uzbekistan in the vicinity of the Iordon settlement.

SPECIMENS SEEN: Alai range, Shakhimardan river basin, surroundings of the Iordon settl., 21 May 1954, leg. Pjataeva (TASH 228).

\section{Cousinia pannosa C. Winkl. (Asteraceae) \\ Cousinia resupinata Juz.}

GENERAL DisTRIBUTION: Central Asia (Tajikistan) (Tscherneva 1991).

OCCURRENCE IN UZBEKISTAN: Cousinia pannosa was known from the western Hissar Mts (Tscherneva 1991), however without specific localities. This is native species in the flora of Uzbekistan, and grows on rocky slopes and steppes in the alpine and subalpine belts, reaching here the western limit of its general range.

SPECIMENS SEEN: The top of the Hodja-Barkhu, at the melting snow on the rocky slope, 6 July 1929, leg. Vvedensky (TASH 443); Pamir Alai, Ulmas Mts, the crest of the ridge, limestone scree in the alpine zone, 10 September 1935, leg. Lepeshkin (TASH 10); Western Hissar, left bank of the river Yuzart, 2500-2700, 13 June 1961, leg. Tuychiev \& Khodzimatov (TASH); Basin of Kashka-Darya, upper reaches of the river Ak-su, subalpine belt, dry rocky slopes of the western and south-western exposure, 13 August 1949, leg. Gomolitsky \& Halmatov (TASH 110); Western Pamir Alai, basin Kyzyl-Darya, tract Okuz-Murgun, northern gravelly slopes at the foot of the Hodja-Akchar, 26 September 1941, leg. Koshurnikova (TASH 801). 
Cousinia tomentella C. Winkl. (Asteraceae)

Arctum tomentellum Kuntze

GENERAL DistRIBUTION: Central Asia (Tajikistan) (Tscherneva 1991).

OCCURRENCE IN UZBEKISTAN: This is native species in the flora of Uzbekistan, reported from Zeravshan range and southern slope of the Hissar Mts. Cousinia tomentella is very close to $C$. umbrosa Bunge, from which it differs by dense arachnoid-tomentose baskets.

SPECIMENS SEEN: Aman-Kutan, north-eastern slope, 7 June 1938, (TASH); Hissar Mts, basin of the Sangardak river, near the road between Bakhcha and the Ak-su river, juniper-maple forest, 3 June 1948, leg. Pjataeva (TASH 146).

\section{Jurinea stenophylla Iljin (Asteraceae)}

General Distribution: Central Asia (Kyrgystan) (Tscherneva 1962, 1993, Tscherneva \& Nikitin 1965, Lazkov \& Sultanova 2011).

OCCURRENCE IN UZBEKISTAN: All known up to date localities of Jurinea stenophylla (Tscherneva and Zuckerwanik, 1993) are situated in Kyrgyzstan along the Uzbekistan border (Padsha-ata river basin, vicinity of Tashkumir town). In TASH, there are three herbarium specimens collected from the Uzbek part of the Western Tian-Shan, which were originally determinated by O.V. Tscherneva as J. suffriticosa, but later, R.V. Kamelin identified it as $J$. stenophylla. Thorough morphological study of these specimens we confirmed Kamelin's determination. Plants collected from the Uzbek part of the Western Tian-Shan differ from the typical $J$. suffriticosa in their concolorous leaves with revolute margins and small yellowish glandules, scarious phyllaries, and the structure of achenes.

SPECIMENS SEEN: Chatkal ridge, middle part of Tashkeskensay hole, $\mathrm{h}=2000-2300 \mathrm{~m}$ a.s.l., 22 July 1960, leg. Petrov (the Chatkal Biosphere Reserve) (TASH); Pass from Aksak-ata river to Maydantal river, sunny places, 15 July 1936, leg. Korotkova \& Titov (TASH 1235); Left bank of Angren river, $0.5 \mathrm{~km}$ to the south of the confluence of Arashan river, 6 July 1954, leg. Nabiev \& Li (TASH 403).

\section{Pedicularis alatauica Stadlm. ex Vved. (Orobanchaceae)}

GENERAL DISTRIBUTION: Pedicularis alatauica occurs in mountain areas of Tian-Shan and Pamir Alai (Kazakhstan, Kyrgyzstan) (Vvedensky 1955, Li 1987).

OCCURRENCE IN UZBEKISTAN: During the analysis of herbarium sheets we found a specimens collected in the western Alai Mts in Uzbekistan.

SPECIMENS SEEN: Pamir Alai, Alai Mts, Shakhimardan river basin, vicinity of Yardan village, river Aksu pass Shuvali, 14 July 1961, leg. Pjataeva (TASH, det. Li); Alai Mts, Shakhimardan river basin, h=4000-45000 m, 4 July 1934, leg. Abdukhakimov (TASH, det. Li); Alai Mts, near Shakhimardan river, 10 July 1965, leg. Shonazarov (TASH 1788); Alai Mts, near Shakhimardan river, 10 July 1965, leg. Shonazarov (TASH 2554).

\section{Pedicularis dolichorhiza Schrenk (Orobanchaceae)}

Pedicularis jugentassica Semiotr.

GENERAL DISTRIBUTION: To date the species is known from Russia, Kazakhstan, Kyrgyzstan, Tajikistan, Afghanistan, India and Iran (Podlech 2012, Li 1987).

OCCURRENCE IN UZBEKISTAN: During the analysis of herbarium sheets we found two new locatities of this species, previously not listed from Uzbekistan.

SPECIMENS SEEN: South-Western Tian-Shan, Chatkal Nature Reserve, Zindan-say, 9 July 1980, leg. Krasovskaya (TASH); South-Western Tian-Shan, Kurama ridge, Betagalik, 10 July 1949, leg. Tschevrenidi (TASH 1360, det. Li). 


\section{Pedicularis sarawschanica Regel (Orobanchaceae)}

General Distribution: Central Asia (Western Pamir Alai; Tajikistan, Turkmenistan) (Vvedensky1955, Li 1987).

OCCURRENCE IN UZBEKISTAN: During revision of herbarium materials (TASH) we found a few sheets with specimens of Pedicularis sarawschanica, which has been not reported previously in Uzbekistan.

SPECIMENS SEEN: Pamir Alai, south-western Hissar, mountain Tschulbair near KhodzhaBarku, 1 July 1941, leg. Popova (TASH, 868; det. Li); Pamir Alai, northern Turkistan range, Zaamin, Sharlik-say pass, 28 July 1941, leg. Korotkova (TASH; det. Li); Western Pamir Alai, Kashka-Darya river basin, Guzar valley near Igri-su settl., h=3000 m, 6 July 1955, leg. Pjataeva (TASH 1664); Western Pamir Alai, Kashka-Darya river basin, Aksu valley near Kyzyl-emchak village, h=3000 m, 15 July 1959, leg. Li \& Zakirov (TASH 850); Western Pamir Alai, Kashka-Darya river basin, Aksu valley near Kyzyl-emchak village, h=3000 m, 15 July 1959, leg. Li \& Zakirov (TASH 835); Pamir Alai, south-western Hissar range, Baisun tau, Khodja Gurgur-ata mountain, 3842'76"N 67²8'67"E; alt. 3229 m; 21 Jun 2013, nº862, O.T. Turginov (TASH).

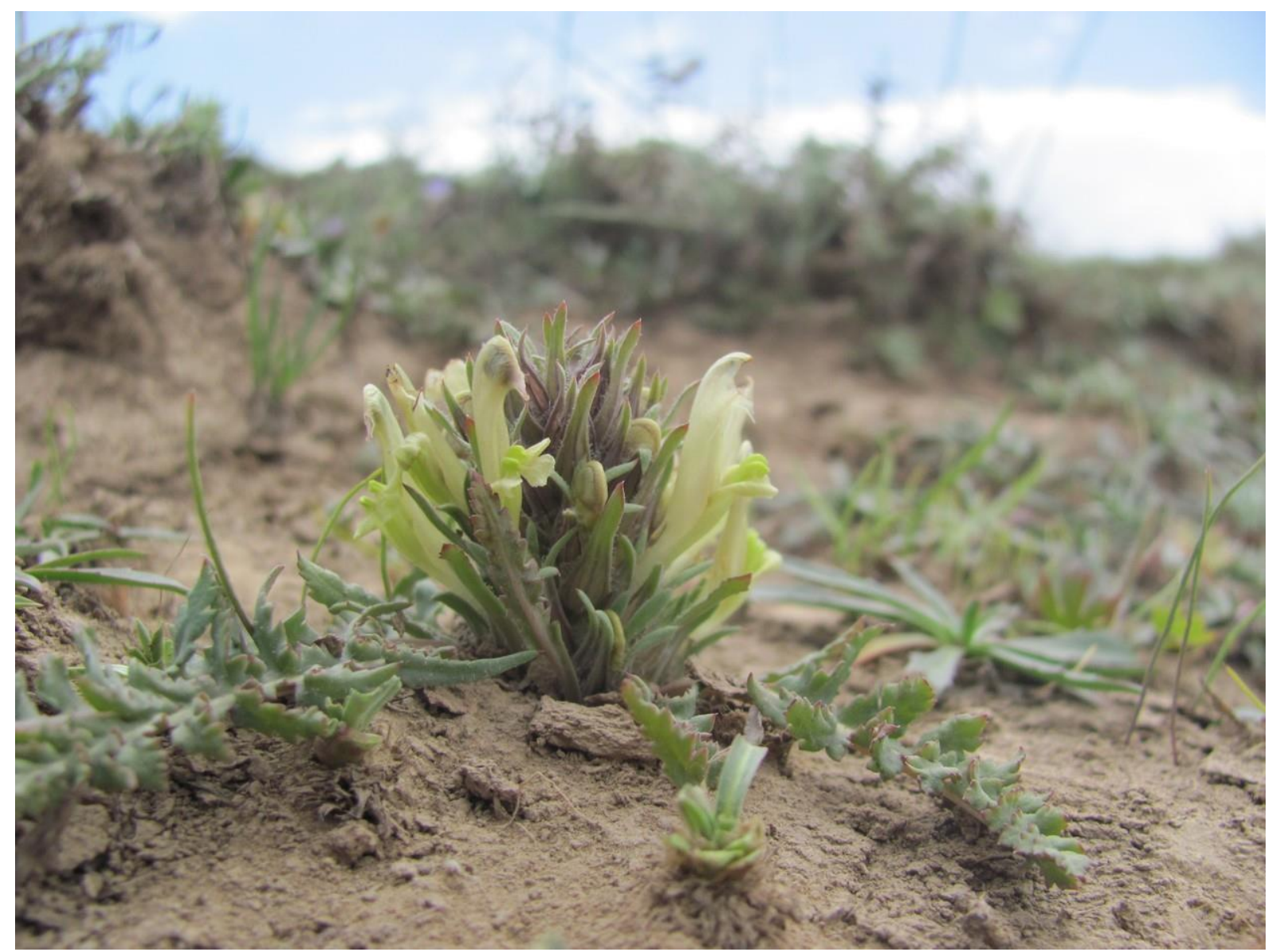

Fig 1: Pedicularis sarawschanica in south-western Hissar range, Baisun tau, Khodja Gurgur-ata mountain. Photo by O.T. Turginov. 


\section{Scrophularia canescens Bong. (Scrophulariaceae)}

GENERAL Distribution: The species is widespread from the plains to the upper belt of mountains of Central Asia (Kazakhstan, Tajikistan), and southern Siberia (Russia) (Abdusalyamova 1986, Gorshkova 1955, Vinogradova \& Shermatov 1987).

OCCURRENCE IN UZBEKISTAN: During the analysis of herbarium collections (TASH) we found three new locations of this taxon in Uzbekistan.

SPECIMENS SEEN: Pamir Alai, south-western Hissar range, near Bandikhan village, 19 August 1940, leg. Popova (TASH 240); Western Pamir Alai, Kashka-Darya river basin, near Guzar village 18 May 1959, leg. Li \& Niyazov (TASH 482); Western Pamir Alai, Kashka-Darya river basin, Aksu valley near Aksu village, 16 July 1937, leg. Kudrjashev (TASH 1544)

\section{References}

Abdusalyamova L.N. (1986): Scrophularia L. - In: Ovczinnikov P.N. (ed.) Flora Tadzhikskoi SSR, 3. Academia Nauk SSSR, Moskva-Leningrad, pp. 340-357.

Gorshkova S.G. (1955) Scrophularia L. - In: Shishkin B.K. \& Bobrov E.G. (eds) Flora SSSR, 22. Academia Nauk SSSR, Moskva- Leningrad, pp. 229-307.

Kovalevskaja S.S. (1959): Chondrilla L. - In: Vvedensky A.I. (ed.) Flora Uzbekistanica, 4. Academia Scientarum UzSSR, Tashkent, pp. 450-454.

Kinzikaeva G.K. (1991): Chondrilla L. - In: Rasulova M.R. (ed.) Flora Tadzhikskoi SSR, 10. Nauka, Leningrad, pp. 413-420.

Lazkov G.A. \& Sultanova B.A. (2011): Checklist of vascular plants of Kyrgyzstan. - Norrlinia 24: 1-166.

Li A.D. (1987): Pedicularis L. - In: Adilov A.T. (ed.) Conspectus Florae Asia Mediae. Fan: Academia Scientarum UzSSR, pp 210-220.

Nobis M., Nowak A., Piwowarczyk R., Ebel A.L., Király G., Kushunina M., Sukhorukov A.P., Chernova O.D., Kipriyanova L.M., Paszko B., Seregin A.P., Zalewska-Gałosz J., Denysenko M., Nejfeld P., Stebel A. \& Gudkova P.D. (2016): Contribution to the flora of Asian and European countries: new national and regional vascular plant records, 5. - Botany Letters 163(2): 159-174.

Podlech D. (2012): Checklist of the Flowering Plants of Afghanistan. München. 301 pp.

Sennikov A.N., Tojibaev K., Khassanov F. \& Beshko N. (2016): The Flora of Uzbekistan Project. Phytotaxa 282: 107-118.

Takhtajan A.L. (1986): Floristic Region of the World. University of California Press, 522 pp.

Tojibaev K.S. (2009): A new species of Tulipa L. (subg. Tulipa) from Uzbekistan. - Linzer Biologische Beiträge 41: 1059-1062.

Tojibaev K.S. \& Turginov O.T. (2013): A new species of the genus Jurinea Cass. (Asteraceae) from the Hissar Range (Pamir Alai). - Botanicheskyi Journal 98: 1563-1566.

- (2014): A new species and a new combination of Iris subgenus Scorpiris (Iridaceae) from Central Asia (Hissar Range, Pamir-Alai). - Phytotaxa 158: 224-228.

Tojibaev K.S., Turginov O. \& Karimov F.I. (2014a): A new species and new records of Allium (Amaryllidaceae) for Uzbekistan (Central Asia). - Phytotaxa 177 (5): 291-297.

Tojibaev K.S., Beshko N.Yu., Turginov O. \& Mirzalieva D. (2014b): New records for Fabaceae in the flora of Uzbekistan. - Flora Mediterranea 24: 25-35.

Tscherneva O.V. (1962): Cousinia Cass. - In: Vvedensky A.I. (ed.) Flora Uzbekistanica, 6. Academia Scientarum UzSSR, Tashkent, pp. 230-331.

- (1991): Cousinia Cass. - In: Rasulova M.R. (ed.) Flora Tadjikiskoi SSR, 10. Nauka, Leningrad, pp. 22-144.

- (1993): Cousinia Cass. - In: Adilov A.T. (ed.) Conspectus Florae Asiae Mediae. Fan, Academia Scientarum UzSSR, pp. 303-352.

Tscherneva O.V. \& Nikitin E.V. (1965): Cousinia Cass. - In: Soronbaeva N.V. (ed.) Flora Kirgizskoi SSR, 11. Nauka, Frunze, pp. 242-296.

Vinogradova R.M. \& Shermatov G.S. (1987): Scrophularia L. - In: Adilov A.T. (ed.) Conspectus Florae Asiae Mediae. Fan: Academia Scientarum UzSSR, pp. 210-220.

Vvedensky A.I. (1955): Pedicularis L. - In: Shishkin B.K. \& Bobrov E.G. (eds) Flora SSSR, 22. Academia Nauk SSSR, Moskva- Leningrad, pp. 687-724. 
Authors' addresses: Komiljon S. Tojibaev, Natalia Yu. Beshko, Orzimat T. Turginov, Farkhod I. Karimov, Avazbek B atashov \& Mansur Usmanov, Institute of Gene Pool of Plants and Animals Academy of Sciences of Uzbekistan, 100125, Durmon yuli st. 32, Tashkent, Uzbekistan.

Marcin Nobis, Institute of Botany, Jagiellonian University, Kopernika 27, 31-501 Krakow, Poland.

E-mail: m.nobis@uj.edu.pl (corresponding author). 